\title{
Local production and action of adrenomedullin in the rat adrenal zona glomerulosa
}

\author{
S Kapas, A Martínez ${ }^{1}$, F Cuttitta ${ }^{1}$ and J P Hinson ${ }^{2}$ \\ Department of Oral Pathology, St Bartholomew's and the Royal London School of Medicine and Dentistry, Turner Street, London E1 2AD, UK, ${ }^{1}$ Cell and \\ Cancer Biology, Division of Clinical Sciences, National Cancer Institute, National Institutes of Health, Rockville, Maryland 20850, USA, and ${ }^{2}$ Department of \\ Biochemistry, Faculty of Basic Medical Sciences, Queen Mary and Westfield College, Mile End Road, London E1 4NS, UK \\ (Requests for offprints should be addressed to J P Hinson, Department of Biochemistry, Faculty of Basic Medical Sciences, Queen Mary and Westfield College, \\ Mile End Road, London E1 4NS, UK)
}

\begin{abstract}
This study was designed to investigate the synthesis and action of adrenomedullin in the rat adrenal gland. The results obtained from in situ hybridization and immunocytochemical studies suggest that adrenomedullin is synthesized not only in the medulla, but also within the zona glomerulosa of the rat adrenal cortex. Findings from in situ hybridization and binding studies also suggested that specific adrenomedullin receptors are expressed in the zona glomerulosa, and that low levels are present in the inner zones of the cortex. The $K_{\mathrm{d}}$ of the zona glomerulosa adrenomedullin receptor $(5.5 \mathrm{nmol} / \mathrm{l})$ suggests that it may respond to locally produced adrenomedullin rather than circulating concentrations of the peptide, which are in a lower range. It was found that adrenomedullin acted on zona glomerulosa cells in vitro to stimulate aldosterone release and
\end{abstract}

cAMP formation, but in this tissue did not stimulate inositol phosphate turnover. The effect of adrenomedullin on aldosterone secretion was significantly attenuated by a protein kinase A inhibitor, suggesting that cAMP mediates the effects of adrenomedullin on aldosterone secretion. Adrenomedullin did not significantly affect the response of zona glomerulosa cells to stimulation by either ACTH or angiotensin II. Adrenomedullin did not affect the release of catecholamines, either adrenaline or noradrenaline, by intact adrenal capsular tissue. These data suggest that both adrenomedullin and its specific receptor are expressed in the rat adrenal zona glomerulosa, leading to the hypothesis that adrenomedullin may have an autocrine/paracrine role in the regulation of the rat adrenal zona glomerulosa.

Journal of Endocrinology (1998) 156, 477-484

\section{Introduction}

Adrenomedullin is a novel hypotensive peptide isolated from a human phaeochromocytoma (Kitamura et al. 1993). It has been shown to be produced by a variety of tissues in addition to the adrenal medulla, and to circulate in picomolar concentrations (Sakata et al. 1994). The cDNA encoding the rat adrenomedullin receptor has recently been cloned (Kapas et al. 1995). The distribution of the receptor is similar to that of the peptide: it is present in the adrenal gland, in addition to the lung and other tissues. It has not been established, however, which regions of the adrenal gland express the gene encoding the receptor. Adrenomedullin is also known to exert some of its effects by binding to the receptor for calcitonin gene-related peptide (CGRP) in some tissues, and this effect is inhibited by CGRP8-37 (Nuki et al. 1993).

Whereas both peptide and receptor have been identified in the adrenal gland, it has not been established whether they are both found in the same region of the gland, and whether adrenomedullin may therefore exert a paracrine/autocrine effect in this gland. It has been suggested that adrenomedullin is produced in the adrenal medulla and may be transported through the gland to act on the zona glomerulosa (Mazzocchi et al. 1996b). Although it is clear that certain neuropeptides may be transported in nerve fibres from the adrenal medulla to the cortex (Hinson 1990), there is no evidence to date that adrenomedullin is found in the nerves supplying the adrenal gland.

Recent studies have investigated the actions of adrenomedullin on the rat adrenal zona glomerulosa, but have suggested that the actions of adrenomedullin may be dependent on the tissue preparation used, as there have been reports of inhibition of aldosterone secretion in dispersed cells (Mazzocchi et al. 1996b, Yamaguchi et al. 1995), but stimulation of aldosterone secretion both in intact capsules and in the intact perfused rat adrenal preparation (Mazzocchi et al. 1996a, Kapas \& Hinson 1996). Adrenomedullin was originally identified by its ability to increase the concentrations of cAMP in platelets. To date, studies on its intracellular actions in the adrenal cortex have implicated both cAMP and the calcium messenger system (Yamaguchi et al. 1995, Kapas \& Hinson 1996). It has not been determined whether adrenomedullin may be produced in the adrenal cortex, although 
previous immunocytochemical studies located it only to the medulla (Washimine et al. 1995) and the zonal distribution of adrenomedullin receptors has not been investigated. The present study was designed to answer these questions, and to determine the actions of adrenomedullin on steroid secretion and second messenger production in the rat adrenal cortex.

\section{Materials and Methods}

All chemicals used were obtained from Sigma Chemical Co. (Poole, Dorset, UK), except adrenomedullin (1-50), $\left[{ }^{125} \mathrm{I}\right]$-adrenomedullin, amylin, CGRP and CGRP8-37 (from Phoenix Pharmaceuticals, Mountain View, CA, USA) and ACTH (Synacthen; Ciba-Geigy, Horsham, Sussex, UK). For in situ hybridization and immunohistochemistry, Sprague-Dawley rats were used, supplied by Science Application International Corp. (Frederick, MD, USA). For other experiments, Wistar rats from the colony maintained at QMW were used.

\section{In situ hybridization and immunocytochemistry}

Four Sprague-Dawley rats were killed by carbon dioxide overdose and immediately perfused with $300 \mathrm{ml}$ of $4 \%$ paraformaldehyde through a heart cannula, with a flow rate of $25 \mathrm{ml} / \mathrm{min}$ (protocol NCI95-125M1). After dissection, the adrenals were cut in half and fixed for $2 \mathrm{~h}$, then paraffin-embedded, following standard procedures.

Detection of the adrenomedullin and adrenomedullin receptor mRNAs was performed using in situ hybridization as described previously (Martínez et al. 1996). The full-length cDNA was ligated into the expression vector pcDNA1 (Kapas et al. 1995) and used to generate riboprobes. The plasmid was linearised with EcoRV and $\mathrm{BamHI}$ and used as a template to synthesize digoxigeninlabelled sense and antisense RNA transcripts. Hybridization was performed in a humidified chamber at $46{ }^{\circ} \mathrm{C}$ for $20 \mathrm{~h}$ in a $20 \mu \mathrm{l}$ volume containing $2.5 \mathrm{ng}$ of probe/ $\mu \mathrm{l}$. After stringency washes, visualization of hybridized probes was performed using a digoxigenin detection kit (Boehringer Mannheim, Indiannapolis, IN, USA). Negative controls included the use of the sense probe and digestion with RNase before hybridization. Previous studies using northern blot analysis have shown that the probes used hybridize with only one band of RNA in the rat adrenal, with a molecular weight corresponding to that of adrenomedullin receptor mRNA (Kapas et al. 1995).

In selected slides, immunocytochemistry for adrenomedullin was performed for the ligand. A previously characterized rabbit antihuman adrenomedullin antibody (Martínez et al. 1995) was used, together with the Vectastain ABC kit (Vector Laboratories, Burlingame, CA, USA), for ligand localization. Negative controls included preincubation of the antibody with $10 \mathrm{ng} / \mathrm{ml}$ synthetic peptide used to generate the antiserum (absorption control), and substitution of the primary antibody by normal rabbit serum. In both cases, immunostaining was totally abolished.

\section{Actions of adrenomedullin on steroid secretion}

Wistar rats were rapidly killed by mechanical stunning followed by cervical dislocation. Adrenal glands were excised and glomerulosa tissue separated from inner zones and medulla by gentle compression between glass plates. Cell suspensions were prepared by collagenase digestion and mechanical dispersal as described previously (Kapas et al. 1992). Zona glomerulosa cells and inner zone (zona fasciculata/reticularis) cells were separately incubated in Krebs bicarbonate Ringer containing $2 \mathrm{mg} / \mathrm{ml}$ glucose and $2 \mathrm{mg} / \mathrm{ml} \mathrm{BSA}$ (fraction V). Cells were incubated in Eppendorf tubes at a density of $10000 / \mathrm{ml}$ in an incubation volume of $1 \mathrm{ml}$, under an atmosphere of $95 \% \mathrm{O}_{2} / 5 \% \mathrm{CO}_{2}$ at $37^{\circ} \mathrm{C}$ for $60 \mathrm{~min}$. Peptide additives were dissolved in incubation medium and added as required. At the end of the incubation, cells were pelleted by centrifugation and aliquots of the incubation medium were assayed for aldosterone (zona glomerulosa cells) and corticosterone (inner zone cells) by radioimmunoassay as previously described (Kapas et al. 1992). All experiments were carried out in duplicate and repeated at least three times.

The role of cAMP-dependent mechanisms in the action of adrenomedullin on zona glomerulosa cells was investigated using HA1004 (Semat Technical, St Albans, Herts, $\mathrm{UK}$ ), a selective inhibitor of protein kinase A (PKA) at the concentration used $(1 \mu \mathrm{mol} / \mathrm{l}$; Hidaka et al. 1984). Dispersed zona glomerulosa cells were incubated as described above, with $100 \mathrm{nmol} / 1$ adrenomedullin, in the presence and absence of HA1004 (1 $\mu \mathrm{mol} / \mathrm{l})$.

\section{Second messengers}

Cells were prepared from Wistar rats as descibed above, and incubated as described above. Aliquots of incubation medium were assayed for cAMP using the competitive binding method previously described (Kapas et al. 1992). Inositol phosphate turnover was assessed by measuring production of inositol triphosphate by $\left[{ }^{3} \mathrm{H}\right]$-inositol-loaded cells as described previously (Kapas et al. 1992).

\section{Binding studies}

These studies were carried out by two different methods. The first method used collagenase-dispersed zona glomerulosa cells (Kapas et al. 1995), and gives values for the number of receptors per cell. This method is not satisfactory for the medulla, however, as the friable medullary cells may be destroyed by the dispersal methods. Briefly, dispersed cells were preincubated for $60 \mathrm{~min}$ in Hepes buffer containing $1 \mathrm{mmol} / \mathrm{l}$ EDTA and then 
incubated in Hepes buffer with $\left[{ }^{125} \mathrm{I}\right]$-adrenomedullin $(2000 \mathrm{Ci} / \mathrm{mmol}$; final concentration $0 \cdot 1 \mathrm{nmol} / \mathrm{l})$ and increasing concentrations of cold peptide, for $60 \mathrm{~min}$ at $22{ }^{\circ} \mathrm{C}$. The final incubation volume was $150 \mu \mathrm{l}$, containing $4-6 \times 10^{5}$ cells. The reaction was terminated by the addition of $800 \mu \mathrm{l}$ of ice-cold incubation buffer to each tube. The cells were then pelleted by centrifugation, washed twice with incubation buffer, and the radioactivity of the pellet measured. All incubations were carried out in triplicate and repeated at least three times.

The second method used homogenates of adrenal tissue, without enzymic and mechanical disruption of the tissue, in order that the receptor content of the medulla could be more satisfactorily investigated. Capsules and inner zone/ medullary tissues were preincubated separately, then homogenized in Hepes buffer with EDTA as above. The remainder of the procedure was then carried out as described above. Protein content of the homogenates was measured by the method of Bradford (1976).

\section{Measurement of catecholamine release}

Intact adrenal capsules were incubated individually in Krebs bicarbonate Ringer in the presence and absence of adrenomedullin at $37^{\circ} \mathrm{C}$ for $1 \mathrm{~h}$. Aliquots of incubation medium were assayed for adrenaline and noradrenaline, using a method based on the trihydroxyindole fluorescence method of Brocklehurst \& Pollard (1990). The technique involves the oxidation of catecholamines by $\mathrm{K}_{2} \mathrm{Fe}(\mathrm{CN})_{6}$ and the subsequent generation of the trihydroxyindole fluorophore product by $\mathrm{NaOH}$ and ascorbic acid. The oxidation reactions are performed under both acidic and neutral $\mathrm{pH}$ conditions to allow measurement of adrenaline and noradrenaline. Briefly, assays were performed as follows. To one set of $50 \mu \mathrm{l}$ samples, $500 \mu \mathrm{l}$ of $0.5 \mathrm{~mol} / 1$ sodium phosphate buffer $(\mathrm{pH} 7 \cdot 0)$ was added; to an another (identical) set of samples, $500 \mu \mathrm{l}$ of $10 \%(\mathrm{v} / \mathrm{v})$ acetic acid was added. All samples received $50 \mu \mathrm{l}$ $\mathrm{K}_{2} \mathrm{Fe}(\mathrm{CN})_{6}$ and were incubated on ice for $20 \mathrm{~min}$. The reactions were terminated with $1 \mathrm{ml} 9 \mathrm{~mol} / 1 \mathrm{NaOH}$ containing $0.4 \%$ ascorbic acid $(\mathrm{w} / \mathrm{v})$, followed by vigorous vortexing. After the addition of $2 \mathrm{ml}$ water, the trihydroxyindole fluorescence product was measured in a spectrofluorimeter (Luminescent fluorimeter LS-50B, Perkin Elmer, Warrington, UK) with an excitation wavelength of $412 \mathrm{~nm}$ and an emission wavelength of $523 \mathrm{~nm}$.

\section{Analysis of data}

Binding data were analysed using LIGAND (Munson \& Rodbard 1980). Steroid and second messenger data were corrected for numbers of cells used and analysed by one-way ANOVA. Student's $t$-test was used only as indicated in the figure legends.

\section{Results}

Immunocytochemistry and in situ hybridization studies revealed the presence of both adrenomedullin peptide and mRNA in the medulla and in the zona glomerulosa, suggesting that adrenomedullin is produced by zona glomerulosa cells (Fig. 1A-C). In these cells, the immunostaining was located in the cytoplasm among the lipidic droplets, which were not stained (Fig. 1C inset). Only very low levels of immunostaining were found in certain cells of the zona fasciculata (Fig. 1C). In situ hybridization with a probe for the adrenomedullin receptor revealed the presence of receptor in the medulla and zona glomerulosa, with smaller amounts in the inner zones of the cortex (Fig. 1D-F). The co-localization of the peptide and the receptor in the same cells suggests the possibility of an autocrine loop for adrenomedullin in the adrenal gland.

Adrenomedullin was found to cause a dose-dependent increase in aldosterone secretion by dispersed zona glomerulosa cells, with a minimum effective concentration of $1 \mathrm{nmol} / 1$ ( $P<0 \cdot 01$; Fig. 2$)$; a maximum response was seen with $100 \mathrm{nmol} / \mathrm{l}$. There was also an increase in cAMP production in response to adrenomedullin (Fig. 2). Incubation of zona glomerulosa cells in the presence of HA1004, the PKA inhibitor, resulted in significant attenuation of the aldosterone response to both adrenomedullin and ACTH, but did not significantly alter basal secretion (Fig. 3).

Adrenomedullin $(100 \mathrm{nmol} / \mathrm{l})$ significantly inhibited both basal $(P<0 \cdot 05)$ and angiotensin II-stimulated $(P<0.001)$ rates of production of inositol trisphosphate (Fig. 4). When zona glomerulosa cells were incubated with adrenomedullin in the presence of other known stimulants of aldosterone secretion, it was found that adrenomedullin had no significant effect on the aldosterone response to either ACTH or angiotensin II (Fig. 5). The CGRP receptor antagonist, CGRP8-37, did not have a significant effect on either basal aldosterone secretion, or the aldosterone response to $100 \mathrm{nmol} / 1$ adrenomedullin (data not shown). Adrenomedullin did not significantly alter the rate of corticosterone secretion by the zona fasciculata/reticularis cells over the concentration range used (data not shown), and was not found to have any effect on the release of either adrenaline or noradrenaline from adrenal capsular tissue (data not shown).

Binding studies using $\left[{ }^{125} \mathrm{I}\right]$-adrenomedullin and dispersed cells revealed a single population of binding sites in the zona glomerulosa (Hill coefficient $0.831, P<0 \cdot 05$ ), with a $K_{\mathrm{d}}$ of $5.5 \mathrm{nmol} / 1$ (Fig. 6). The concentration of binding sites was found to be $400 \mathrm{fmol} / 10^{6}$ cells. Binding studies using $\left[{ }^{125} \mathrm{I}\right]$-adrenomedullin and adrenal homogenate cells also revealed a single population of binding sites in the zona glomerulosa (Hill coefficient 0.89, $P<0 \cdot 05)$, with a $K_{\mathrm{d}}$ of $4.45 \mathrm{nmol} / \mathrm{l}$. The concentration of 

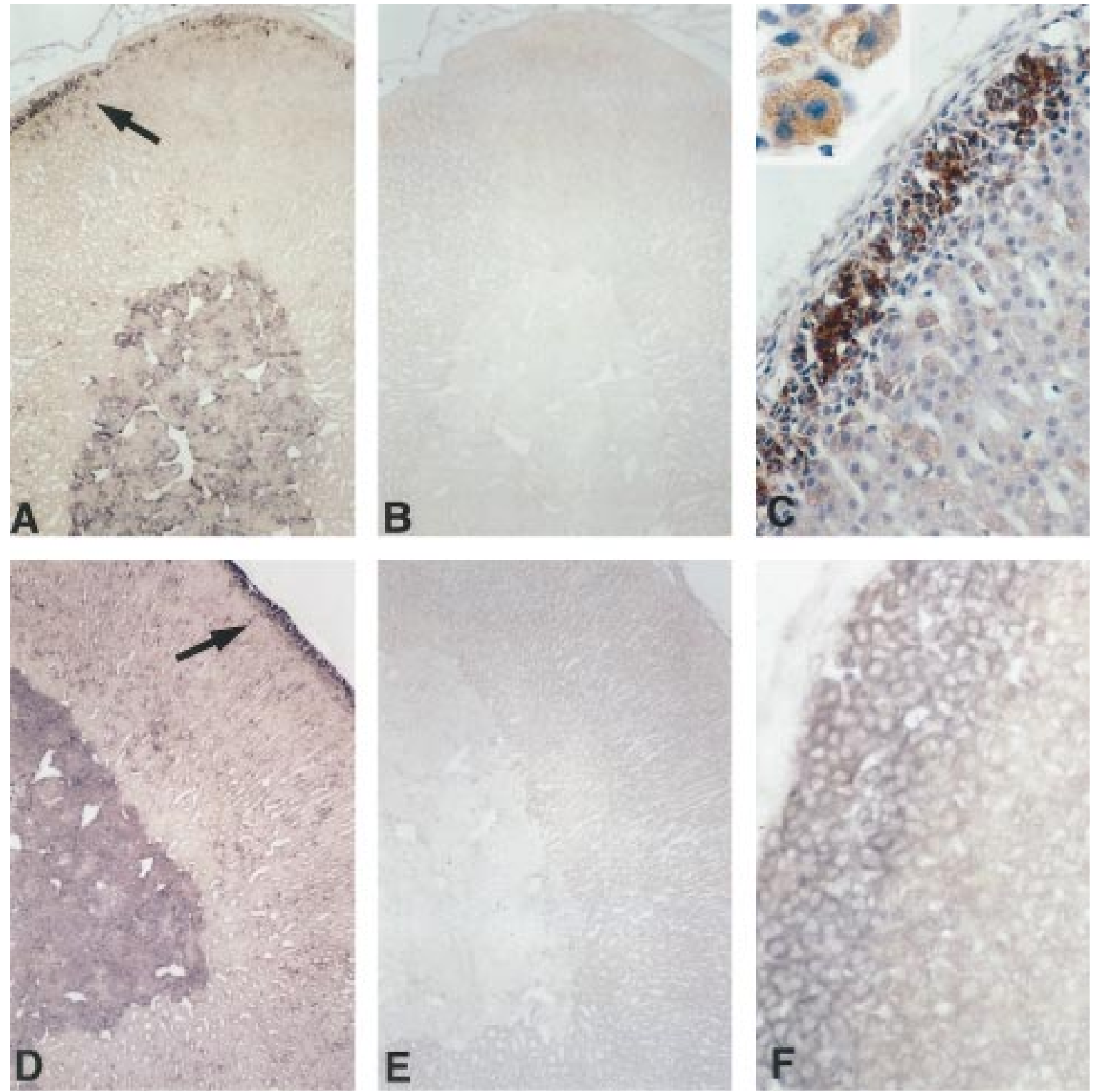

Figure 1 Paraffin sections of rat adrenals, showing the distribution of adrenomedullin and adrenomedullin receptor mRNAs and adrenomedullin protein. (A) In situ hybridization with the adrenomedullin antisense probe, demonstrating staining in both the medulla and the peripheral cortex (arrow). (B) Serial section hybridized with the sense probe as a negative control. Magnification, $\times 60$. (C) Detail of the zona glomerulosa after immunocytochemical staining with antiadrenomedullin antibody. Magnification, $\times 300$. Inset: Higher magnification of some zona glomerulosa cells in which the cytoplasmic distribution of the immunoreactivity can be distinguished. Magnification $\times 750$. (D) In situ hybridization for adrenomedullin receptor. The distribution of the adrenomedullin receptor mRNA is very similar to that shown by the adrenomedullin mRNA: both the medulla and the zona glomerulosa (arrow) stain with the antisense probe. (E) Negative control using the adrenomedullin receptor sense probe. Magnification $\times 60$. (F) Detail of the zona glomerulosa after hybridization with the adrenomedullin receptor probe. Magnification, $\times 300$.

binding sites was $378 \mathrm{fmol} / \mathrm{mg}$ protein. In the inner zone/medullary homogenates there were $570 \mathrm{fmol}$ binding sites $/ \mathrm{mg}$ protein with a $K_{\mathrm{d}}$ of $3.64 \mathrm{nmol} / 1$ (Hill coefficient $0 \cdot 98, P<0 \cdot 05)$.
Binding of $\left[{ }^{125} \mathrm{I}\right]$-adrenomedullin was not significantly displaced by the adrenal stimulants angiotensin II or corticotrophin in homogenates of either zona glomerulosa or inner zone/medullary tissue. CGRP did, however, 


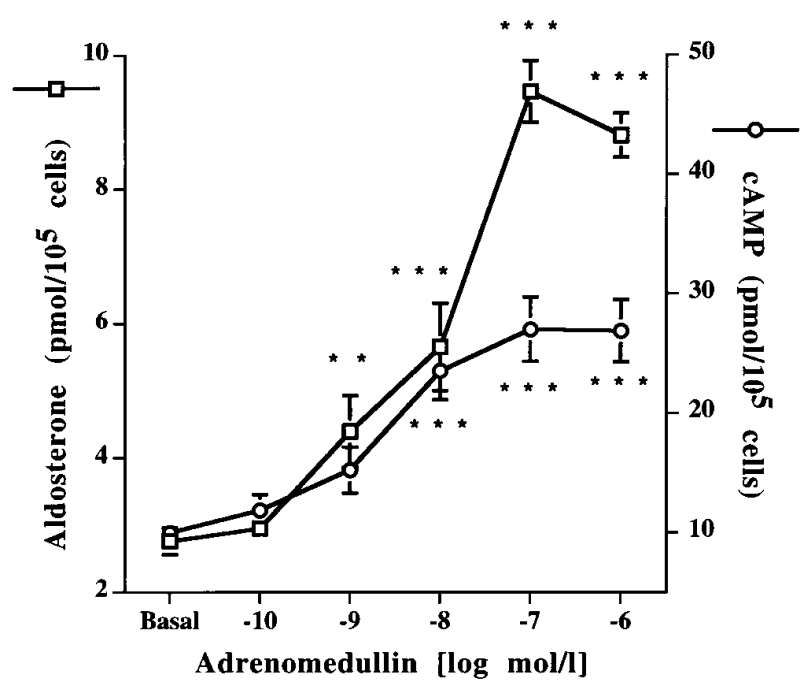

Figure 2 Effects of increasing concentrations of adrenomedullin on release of aldosterone $(\square)$ and CAMP $(\bigcirc)$ from dispersed rat zona glomerulosa cells. Values are means \pm S.E.M.. of four separate experiments each carried out in duplicate. ${ }^{* *} P<0 \cdot 01,{ }^{* *} P<0 \cdot 001$ compared with basal values.

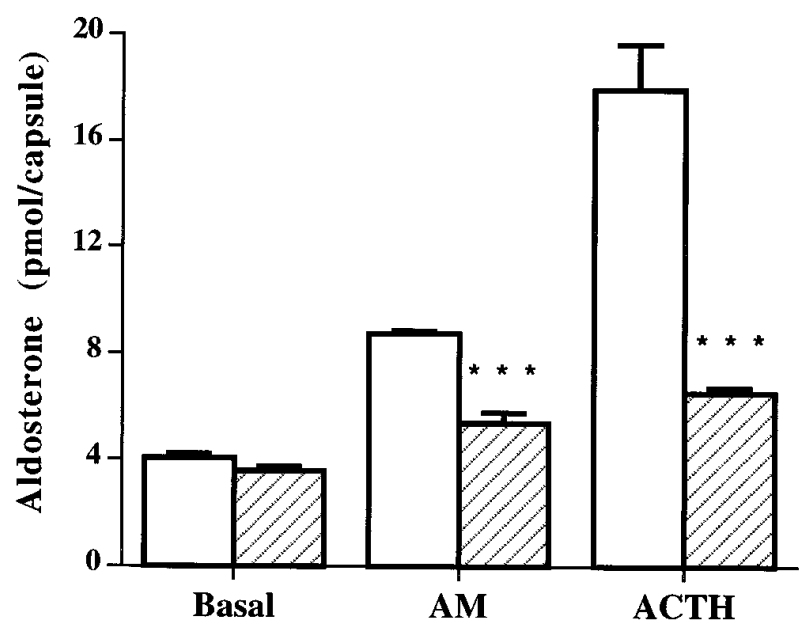

Figure 3 Effects of HA1004, a PKA inhibitor $(1 \mu \mathrm{mol} / \mathrm{l})$, on basal and adrenomedullin $(1 \mu \mathrm{mol} / \mathrm{l})$ - and ACTH $(1 \mathrm{nmol} / \mathrm{l})$-stimulated aldosterone secretion. Open bars, without HA1004; cross-hatched bars, with HA1004. Values are means+S.E.M.. of four separate experiments each carried out in duplicate. ${ }^{* *} P<0 \cdot 001$ compared with value obtained in absence of HA1004.

displace a proportion of the bound adrenomedullin in both tissues, suggesting the presence of CGRP receptors and amylin-displaced binding in the inner zone/medullary tissue (Table 1).

\section{Discussion}

The results presented suggest that adrenomedullin, in addition to its synthesis in the medulla, is synthesized

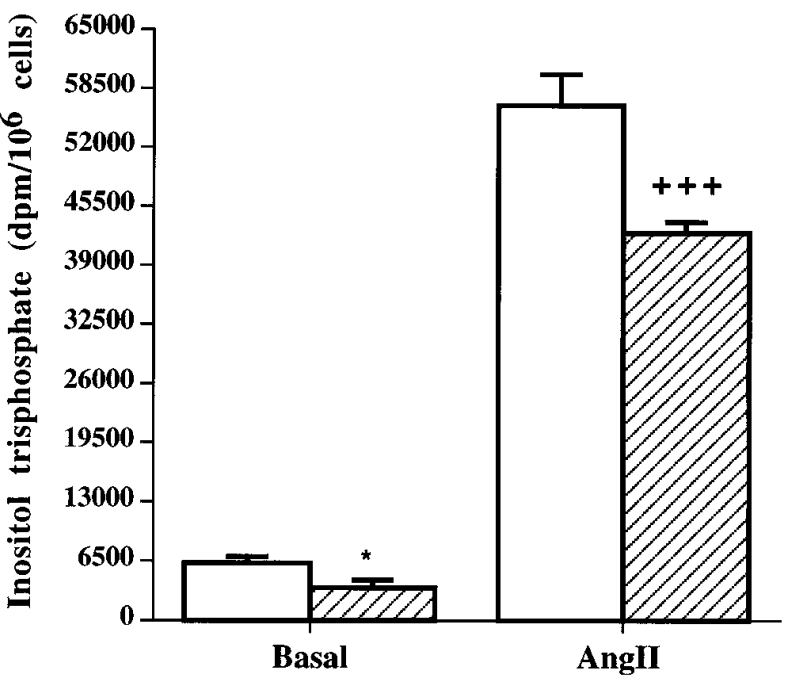

Figure 4 Effects of adrenomedullin $(100 \mathrm{nmol} / \mathrm{l})$ on basal and angiotensin II ( $1 \mu \mathrm{mol} / \mathrm{l})$-stimulated inositol trisphosphate production by adrenal zona glomerulosa cells. Open bars, without adrenomedullin; cross-hatched bars, with adrenomedullin. Values are means+S.E.M. of six experiments each carried out in duplicate. ${ }^{*} P<0.05$ compared with basal, ${ }^{* *} P<0.001$ compared with angiotensin II-stimulated inositol trisphosphate production.

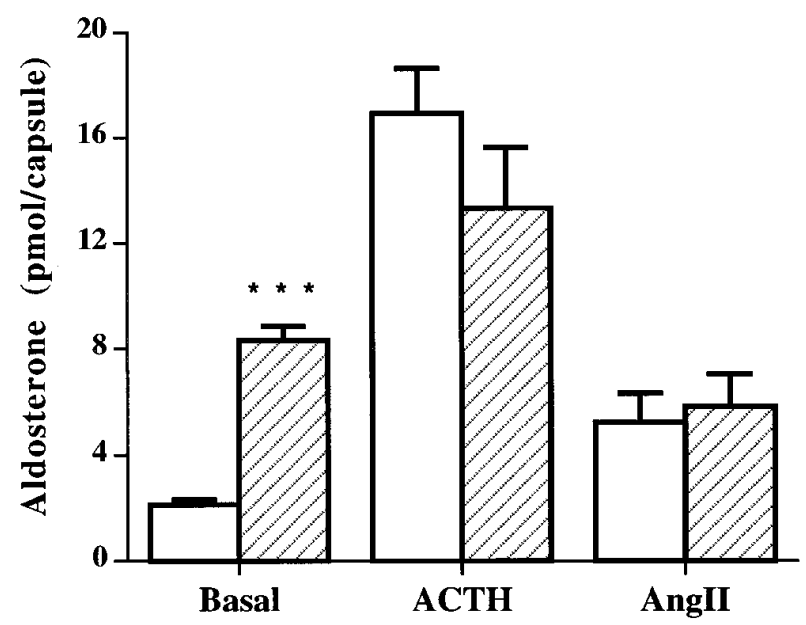

Figure 5 Effects of adrenomedullin $(100 \mathrm{nmol} / \mathrm{l})$ on basal aldosterone secretion and on the response to ACTH $(1 \mathrm{nmol} / \mathrm{l})$ and angiotensin II $(1 \mu \mathrm{mol} / \mathrm{l})$. Open bars, without adrenomedullin; cross-hatched bars, with adrenomedullin. Values are means+S.E.M. of four separate experiments each carried out in duplicate. $* * * P<0 \cdot 001$ compared with control.

in the zona glomerulosa of the rat adrenal cortex. This observation confirms previous reports of the adrenal medulla as a source of this peptide, but also raises the possibility of local synthesis of adrenomedullin in the zona glomerulosa. It has been reported that adrenomedullin is synthesized by some endothelial cells (Sugo et al. 1994), which are abundant throughout the adrenal cortex, but it 


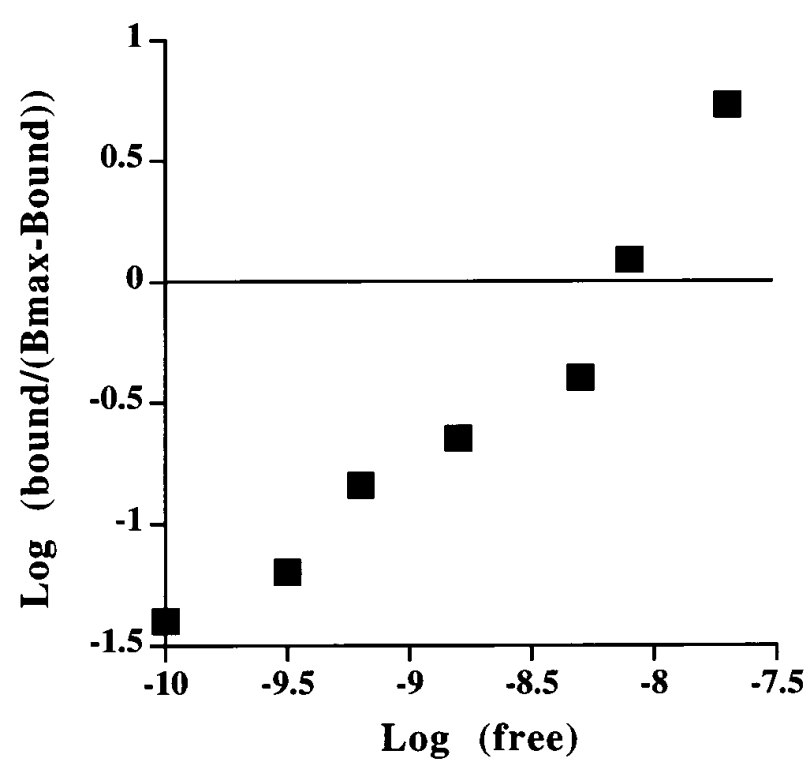

Figure 6 Hill plot of $\left[{ }^{125} \mathrm{I}\right]$-adrenomedullin binding to zona glomerulosa cells. Hill coefficient $0 \cdot 831, P<0 \cdot 05$, Bmax $=400 \mathrm{fmol} / 10^{6}$ cells, $K_{\mathrm{d}} 5 \cdot 5 \mathrm{nmol} / \mathrm{l}$.

Table 1 Displacement of $\left[{ }^{125} \mathrm{I}\right]$-adrenomedullin specific binding in rat adrenal homogenates by adrenomedullin and other peptides, all used at $50 \mu \mathrm{mol} / \mathrm{l}$. Values are means \pm S.E.M.

\begin{tabular}{lccc} 
& $\begin{array}{c}\text { Zona glomerulosa } \\
\text { (\% displacement) }\end{array}$ & & $\begin{array}{c}\text { Inner zones/medulla } \\
\text { (\% displacement) }\end{array}$ \\
\cline { 2 - 2 } Adrenomedullin & $100 \pm 10^{* * *}$ & & $100 \pm 11^{* * *}$ \\
CGRP & $20 \pm 4^{*}$ & & $15 \pm 3^{*}$ \\
Amylin & $5 \pm 0 \cdot 6$ & & $13 \pm 4^{*}$ \\
Angiotensin II & $10 \pm 2$ & $3 \pm 0 \cdot 5$ \\
ACTH & $8 \pm 1$ & $1 \pm 0 \cdot 8$ \\
\cline { 2 - 3 } & & \\
\hline
\end{tabular}

Significant displacement of $\left[{ }^{125} \mid\right]$-adrenomedullin specific binding was obtained with adrenomedullin $(* * * P<0 \cdot 001)$, CGRP and, in the inner zones/medulla, with amylin $\left({ }^{*} P<0 \cdot 05\right)$, but not with angiotensin II or corticotrophin.

would seem unlikely that these cells are the source of the adrenocortical adrenomedullin, as the synthesis of this peptide appears to be restricted mainly to the zona glomerulosa region. In addition, endothelial cells of the adrenal did not show staining for adrenomedullin by either immunocytochemistry or in situ hybridization. Our data suggest that the zona glomerulosa cells themselves are the sites of adrenomedullin synthesis (Fig. 1), together with the medulla. While this is the first report of adrenomedullin synthesis in the adrenal zona glomerulosa, it is well established that other peptide hormones, such as the vasoactive peptide, endothelin, are synthesized by the rat adrenal zona glomerulosa (Imai et al. 1992).

There is some controversy in the literature as to whether adrenomedullin stimulates (Mazzocchi et al. 1996a, Kapas \& Hinson 1996) or inhibits (Mazzocchi et al. 1996b, Yamaguchi et al. 1995) secretion of aldosterone by rat adrenals. Similar diametrical effects have been observed with respect to insulin secretion, some studies demonstrating inhibition (Martínez et al. 1996) and others reporting stimulation (Mulder et al. 1996), and to growth, in which adrenomedullin could act as a growth factor (Miller et al. 1996, Withers et al. 1996) or an inhibitor (Kano et al. 1996).

In the adrenal cortex, the actions of adrenomedullin reported previously appeared to indicate that the effects of this peptide may depend on the tissue preparation used, as adrenomedullin was shown to stimulate aldosterone secretion by intact tissue preparations such as capsules or the perfused adrenal preparation, but inhibit aldosterone secretion when dispersed cells were studied. In a recent in vivo study this view was challenged, however, by the demonstration of inhibition of the aldosterone response to sodium depletion in rats (Yamaguchi et al. 1996). There is also evidence for a stimulatory effect of adrenomedullin in frog adrenal slices (Esneu et al. 1996). In the present studies, however, we observed a significant increase in aldosterone secretion by dispersed cells in response to adrenomedullin, in direct opposition to the findings of Yamaguchi et al. (1995) and Mazzocchi et al. (1996b).

In an attempt to resolve this difference, we investigated the generation of second messengers in response to adrenomedullin, and found a significant, dose-dependent increase in cAMP, but an inhibition of inositol phosphate turnover. Furthermore, the aldosterone response to adrenomedullin was significantly attenuated by a PKA inhibitor, suggesting that cAMP mediates the effects of adrenomedullin on aldosterone secretion in this preparation. Previous studies have revealed that adrenomedullin inhibits the response to angiotensin II (Yamaguchi et al. 1995, Mazzocchi et al. 1996b). We found that adrenomedullin inhibited the increase in inositol phosphate turnover stimulated by angiotensin II, but the aldosterone response to angiotensin II in the presence of adrenomedullin did not differ significantly from that to angiotensin II alone (although it was lower than the response to adrenomedullin alone). The actions of adrenomedullin on inositol trisphosphate production and the response to angiotensin II closely resemble the actions of ACTH, a known adrenocortical stimulant, well recognized to act through cAMP (Kapas et al. 1994). The results of the present study, however, do not exclude the possibility that adrenomedullin may alter intracellular $\mathrm{Ca}^{2+}$ concentrations by a mechanism independent of inositol trisphosphate, as has been suggested by others (Yamaguchi et al. 1995, Andreis et al. 1997).

In experiments on human adrenal slices, Andreis et al. (1997) demonstrated an effect of adrenomedullin on catecholamine release and suggested that this may explain the discrepancies between the different tissue preparations. In the present study, we found that adrenomedullin did not alter catecholamine release by rat adrenal capsular tissue. This is in agreement with previous reports suggesting that 
adrenomedullin has no effect on medullary catecholamine release (Houchi et al. 1996, Watanabe et al. 1996), which is consistent with its action as a vasodilator. It may, however, indicate that peptide degradation has occurred during the course of these studies, as a truncated form of adrenomedullin has been shown to stimulate catecholamine release (Champion et al. 1996).

The results obtained from the in situ hybridization and the binding studies suggest that specific receptors for adrenomedullin are present in the zona glomerulosa, in the same cells that contain the adrenomedullin peptide. The $K_{\mathrm{d}}$ values of these receptors, found to be in the nanomolar range, suggest that the zona glomerulosa may respond to locally produced adrenomedullin, rather than the circulating peptide, as the plasma concentration of adrenomedullin has been reported to be around $5 \mathrm{pmol} / 1$ (Sakata et al. 1994). Previous studies using the CGRP antagonist, CGRP 8-37, have suggested that the effects of adrenomedullin on the rat adrenal are mediated by the CGRP receptor (Mazzocchi et al. 1996b). The results of the present study do not support this hypothesis: only $20 \%$ of the specific adrenomedullin binding to the zona glomerulosa could be displaced by CGRP, and in our hands the CGRP antagonist had no significant effect on adrenomedullin-stimulated aldosterone secretion. Together with the in situ hybridization demonstrating adrenomedullin receptor mRNA in the zona glomerulosa, these data suggest that the effects of adrenomedullin on aldosterone secretion are mediated by the specific adrenomedullin receptor. This may go some way to explaining the discrepancy between the results of the present study and those obtained by Mazzocchi et al. (1996b). It is possible that, in some rats, the adrenal expresses the CGRP receptor, and adrenomedullin acting through this receptor has an inhibitory effect, but that in other types of rat, which express the adrenomedullin receptor, a stimulatory effect on the adrenal cortex may be seen.

The data presented in this study strongly suggest that adrenomedullin is a paracrine or autocrine factor in the zona glomerulosa. This has been observed previously in tumour cells (Mulder et al. 1996) and in developing embryos (Montuenga et al. 1997). There is evidence both for the production of adrenomedullin by the zona glomerulosa and for the presence of specific receptors; in addition, a clear biological effect of adrenomedullin on zona glomerulosa function has been demonstrated. In several respects, the actions of adrenomedullin on the rat zona glomerulosa resemble the actions of ACTH: both peptides stimulate aldosterone and cAMP release, with the well-recognized order-of-magnitude difference in the dose-response curves (Kapas et al. 1992); the actions of both peptides are attenuated by a PKA inhibitor; and neither peptide has an additive effect with angiotensin II (Kapas et al. 1994). However, the physiological role of adrenomedullin in the rat zona glomerulosa requires elucidation. ACTH is a potent stimulus to zona glomerulosa function in the short term but, when administered over a longer time period, it significantly attenuates aldosterone secretion (Abayasekara et al. 1989). The regulation of local adrenomedullin biosynthesis and the long-term actions of this peptide in the zona glomerulosa clearly require further study.

\section{Acknowledgements}

We are grateful to the Royal Society and the British Heart Foundation for grant support for these studies.

\section{References}

Abayasekara DRE, Vazir H, Whitehouse BJ, Price GM, Hinson JP \& Vinson GP 1989 Studies on the mechanisms of ACTH-induced inhibition of aldosterone biosynthesis in the rat adrenal cortex. Journal of Endocrinology 122 625-632.

Andreis PG, Neri G, Prayer-Galetti T, Rossi GP, Gottardo G, Malendowicz LK \& Nussdorfen GG 1997 Effects of adrenomedullin on the human adrenal gland: an in vitro study. Journal of Clinical Endocrinology and Metabolism 82 1167-1170.

Bradford MM 1976 A rapid and sensitive method for the quantitation of microgram quantities of protein utilising the principle of protein-dye binding. Analytical Biochemistry 72 248-254.

Brocklehurst KW \& Pollard HB 1990 In Peptide Hormone Secretion: A Practical Approach, pp 235-238. Eds JC Hutton \& K Siddle. Oxford: IRL Press.

Champion HC, Fry RC, Murphy WA, Coy DH \& Kadowicz PJ 1996 Catecholamine release mediates pressor effects of adrenomedullin (15-22) in the rat. Hypertension 28 1041-1046.

Esneu M, Delarue C, Fournier A \& Vaudry H 1996 Characterization of the receptor mediating the effect of calcitonin gene-related peptide in the frog adrenal gland. European Journal of Pharmacology 308 187-193.

Hidaka H, Inagaki M, Kawamoto S \& Sasaki Y 1984 Isoquinolinosulfonamides, novel and potent inhibitors of cyclic nucleotide dependent protein kinase and protein kinase C. Biochemistry 23 5036-5041.

Hinson JP 1990 Paracrine control of adrenocortical function: a new role for the medulla? Journal of Endocrinology 124 7-9.

Houchi H, Yoshizumi M, Shono M, Ishimura Y, Ohuchi T \& Oka M 1996 Adrenomedullin stimulates calcium efflux from adrenal chromaffin cells in culture: possible involvement of an $\mathrm{Na}^{2+} / \mathrm{Ca}^{2+}$ exchange mechanism. Life Sciences 58 PL35-40.

Imai T, Hirata Y, Eguchi S, Kann K, Ohta K, Emori T, Sakamoto A, Yanagisawa M, Masaki T \& Marumo F 1992 Concomitant expression of receptor subtype and isopeptide of endothelin by human adrenal gland. Biochemical and Biophysical Research Communications 182 1115-1121.

Kano H, Kohno M, Yasunari K, Yokokawa K, Horio T, Ikeda M, Minami M, Hanehira T, Takeda T \& Yoshikawa J 1996 Adrenomedullin as a novel antiproliferative factor of vascular smooth muscle cells. Journal of Hypertension 14 209-213.

Kapas S \& Hinson JP 1996 Actions of adrenomedullin on the rat adrenal cortex. Endocrine Research 22 861-865.

Kapas S, Orford CD, Barker S, Vinson GP \& Hinson JP 1992 Studies on the intracellular mechanism of action of $\alpha$-melanocytestimulating hormone on rat adrenal zona glomerulosa. Journal of Molecular Endocrinology 9 47-54.

Kapas S, Purbrick A, Barker S, Vinson GP \& Hinson JP 1994 Alphamelanocyte stimulating hormone-induced inhibition of angiotensin II receptor-mediated events in the rat adrenal zona glomerulosa. Journal of Molecular Endocrinology 13 95-104. 
Kapas S, Catt KJ \& Clark AJL 1995 Cloning and expression of cDNA encoding a rat adrenomedullin receptor. Journal of Biological Chemistry $27025344-25347$.

Kitamura K, Kangawa K, Kawamoto M, Ichiki Y, Nakamura S, Matsuo H \& Eto T 1993 Adrenomedullin: a novel hypotensive peptide isolated from human adrenal phaeochromocytoma. Biochemical and Biophysical Research Communications 192 553-560.

Martínez A, Miller MJ, Unsworth EJ, Siegfried JM \& Cuttitta F 1995 Expression of adrenomedullin in normal human lung and in pulmonary tumors. Endocrinology 136 4099-4105.

Martínez A, Weaver C, López J, Bhathena SJ, Elsasser TH, Miller MJ, Moody TW, Unsworth EJ \& Cuttitta F 1996 Regulation of insulin secretion and blood glucose metabolism by adrenomedullin. Endocrinology $1372626-2632$.

Mazzocchi G, Musajo F, Neri G, Gottardo G \& Nussdorfer GG 1996a Adrenomedullin stimulates steroid secretion by the isolated perfused rat adrenal gland in situ: comparison with calcitonin gene-related peptide effects. Peptides 17 853-857.

Mazzocchi G, Rebuffat P, Gottardo G \& Nussdorfer GG $1996 b$ Adrenomedullin and calcitonin gene-related peptide inhibit aldosterone secretion in rats, acting via a common receptor. Life Sciences 58 839-844.

Miller MJ, Martínez A, Unsworth EJ, Thiele CJ, Moody TW \& Cuttitta F 1996 Adrenomedullin expression in human tumor cell lines: its potential role as an autocrine growth factor. Journal of Biological Chemistry 271 23345-23351.

Montuenga LM, Martínez A, Miller MJ, Unsworth EJ \& Cuttitta F 1997 Expression of adrenomedullin and its receptor during embryogenesis suggests autocrine or paracrine modes of action. Endocrinology 138 440-451.

Mulder H, Ahren B, Karlsson S \& Sundler F 1996 Adrenomedullin: localization in the gastrointestinal tract and effects on insulin secretion. Regulatory Peptides 62 107-112.

Munson PJ \& Rodbard D 1980 Ligand: a versatile computerised approach for characterization of ligand-binding systems. Analytical Biochemistry 107 220-239.
Nuki C, Kawasaki H, Kitamura K, Takenaga M, Kangawa K, Eto T \& Wada A 1993 Vasodilator effect of adrenomedullin and calcitonin gene-related peptide receptors in rat mesenteric vascular beds. Biochemical and Biophysical Research Communications 196 245-251.

Sakata J, Shimokubo T, Kitamura K, Nishizono M, Iehiki Y, Kangawa K, Matsuo H \& Eto T 1994 Distribution and characterization of immunoreactive rat adrenomedullin in tissue and plasma. FEBS Letters 352 105-108.

Sugo S, Minamino N, Kangawa K, Miyamoto K, Kitamura K, Sakata J, Eto T \& Matsuo H 1994 Endothelial cells actively synthesise and secrete adrenomedullin. Biochemical and Biophysical Research Communications 201 1160-1166.

Washimine H, Asada Y, Kitamura K, Ichiki Y, Hara S, Yamamoto Y, Kangawa K, Sumiyoshi A \& Eto T 1995 Immunohistochemical identification of adrenomedullin in human, rat and porcine tissues. Histochemistry 103 251-254.

Watanabe TX, Itahara Y, Inui T, Yoshizawakumagaye K, Nakajima K \& Sakakibara S 1996 Vasopressor activities of N-terminal fragments of adrenomedullin in anaesthetised rat. Biochemical and Biophysical Research Communications 219 59-63.

Withers DJ, Coppock HA, Seufferlein T, Smith DM, Bloom SR \& Rozengurt E 1996 Adrenomedullin stimulates DNA synthesis and cell proliferation via elevation of cAMP in Swiss 3 T3 cells. FEBS Letters 378 83-87.

Yamaguchi T, Baba K, Doi Y \& Yano K 1995 Effect of adrenomedullin on aldosterone secretion by dispersed rat adrenal zona glomerulosa cells. Life Sciences 56 379-387.

Yamaguchi T, Baba K, Doi Y, Yano K, Kitamura K \& Eto T 1996 Inhibition of aldosterone production by adrenomedullin, a hypotensive peptide, in the rat. Hypertension 28 308-314.

Received 25 April 1997

Revised manuscript received 8 August 1997

Accepted 1 October 1997 